\title{
EFFECT OF NITROUS OXIDE ON FOLATE COENZYME DISTRIBUTION AND DE NOVO SYNTHESIS OF THYMIDYLATE IN HUMAN BONE MARROW CELLS
}

\author{
A. A. M. Ermens, M. Schoester, J. Lindemans and J. Abels \\ Institute of Hematology Ee2202, Erasmus University Rotterdam, PO Box 1738, 3000 DR Rotterdam, \\ The Netherlands
}

(Received 21 November 1990; revisions received 7 May 1991)

\begin{abstract}
The effect of nitrous oxide on intracellular folate metabolism of the human bone marrow was studied in vitro. Bone marrow cells, obtained from healthy volunteers, were incubated with $5 \times 10^{-8} \mathrm{M}$ $\left[{ }^{3} \mathrm{H}\right] 5$-formyltetrahydrofolate (5-formylTHF) for $18 \mathrm{hr}$ to label intracellular folate pools. Subsequently the cells were exposed to nitrous oxide for up to $10 \mathrm{hr}$, and the intracellular folate coenzyme levels were quantitated by HPLC. The dU suppression test was carried out on part of the bone marrow samples in order to measure folate-dependent synthesis of the DNA precursor thymidylate (dTMP). After $5 \mathrm{hr}$ exposure to nitrous oxide the de novo dTMP synthesis of the bone marrow cells was significantly decreased $(P<0.05)$, and this reduced synthesis persisted at $10 \mathrm{hr}$. After both 5 and $10 \mathrm{hr}$ of exposure to nitrous oxide the amount of 10 -formylTHF was reduced $(P<0.05)$ while that of 5 -methylTHF was increased $(P<0.05)$. At $10 \mathrm{hr}$ the level of THF was also decreased $(P<0.05)$. This study shows that nitrous oxide exposure of human bone marrow cells causes a redistribution of the various folate coenzymes which supports the idea of 'functional cobalamin deficiency'. Moreover it seems probable that following prolonged exposure to nitrous oxide, not only folate-dependent dTMP synthesis but also de novo purine synthesis is reduced.
\end{abstract}

\section{INTRODUCTION}

Several clinical studies have shown that prolonged exposure to the anaesthetic gas nitrous oxide can cause bone marrow depression (Amess et al., 1978; Chanarin et al., 1985; Skacel et al., 1983). This phenomenon may be explained by the fact that nitrous oxide specifically inactivates the methylcobalamin coenzyme of methionine synthase. This enzyme plays a crucial role in the cellular metabolism of reduced folates by conversion of homocysteine and 5-methyltetrahydrofolate (5-methylTHF), the major extracellular folate, to methionine and tetrahydrofolate (THF) (Fig. 1). Prolonged exposure to nitrous oxide therefore causes accumulation of 5-methylTHF at the expense of other reduced folates that form the quintessence of the 'methylfolate trap' hypothesis of functional cobalamin deficiency (Herbert and Zalusky, 1962), which recently has come under considerable criticism (Deacon et al., 1990). As a result of the disturbed folate-dependent methylation reactions, impairment of the de novo synthesis of the DNA precursor thymidylate (dTMP) occurs. Obviously the rapidly dividing cells of the haematopoietic compartment are very dependent on the intact function of the methylcobalamin coenzyme.

The widespread use of nitrous oxide has evoked general interest in the possible toxicity of this anaes-

Abbreviations: $\mathrm{BSA}=$ bovine serum albumin; dTMP = thymidylate; FCS = foetal calf serum; HBSS $=$ Hanks' balanced salt solution; THF $=$ tetrahydrofolate. thetic gas. Several clinical studies on haematotoxic effects have therefore been performed (Amess $e t$ al., 1978; Skacel et al., 1983). However, metabolic research on nitrous oxide and its effects on intracellular folate metabolism has been limited to laboratory animals and cell lines (Boss, 1985; Wilson and Horne, 1986). This may be explained by the fact that studies on human material (ex vivo) have been hampered by the instability of the various folate coenzymes and even more by their low intracellular concentration (Duch et al., 1983; Pheasant et al., 1983; Wilson and Horne, 1986). The major objective of the present work was to determine the folate coenzyme distribution in fresh human bone marrow cells during exposure in vitro to nitrous oxide and to correlate these results with disturbances of folate-dependent dTMP synthesis.

\section{MATERIALS AND METHODS}

Chemicals. 5-FormylTHF was obtained from Lederle (Etten-Leur, The Netherlands). The premixed gas cylinder containing $50 \%$ nitrous oxide, $20 \%$ oxygen, $25 \%$ nitrogen and $5 \%$ carbon dioxide was purchased from Hoekloos (Schiedam, The Netherlands). $3^{\prime}, 5^{\prime}, 7^{\prime}\left[{ }^{3} \mathrm{H}\right]$ (6S) 5-formylTHF (sp. act. $40 \mathrm{Ci} / \mathrm{mmol}$ ) was obtained from Moravek Biochemicals (Brea, CA, USA). Bovine serum albumin (BSA) was obtained from Sigma Chemical Co. (St Louis, MO, USA), Lymphoprep was obtained from Mycomed (Oslo, Norway) and foetal calf serum (FCS) was 


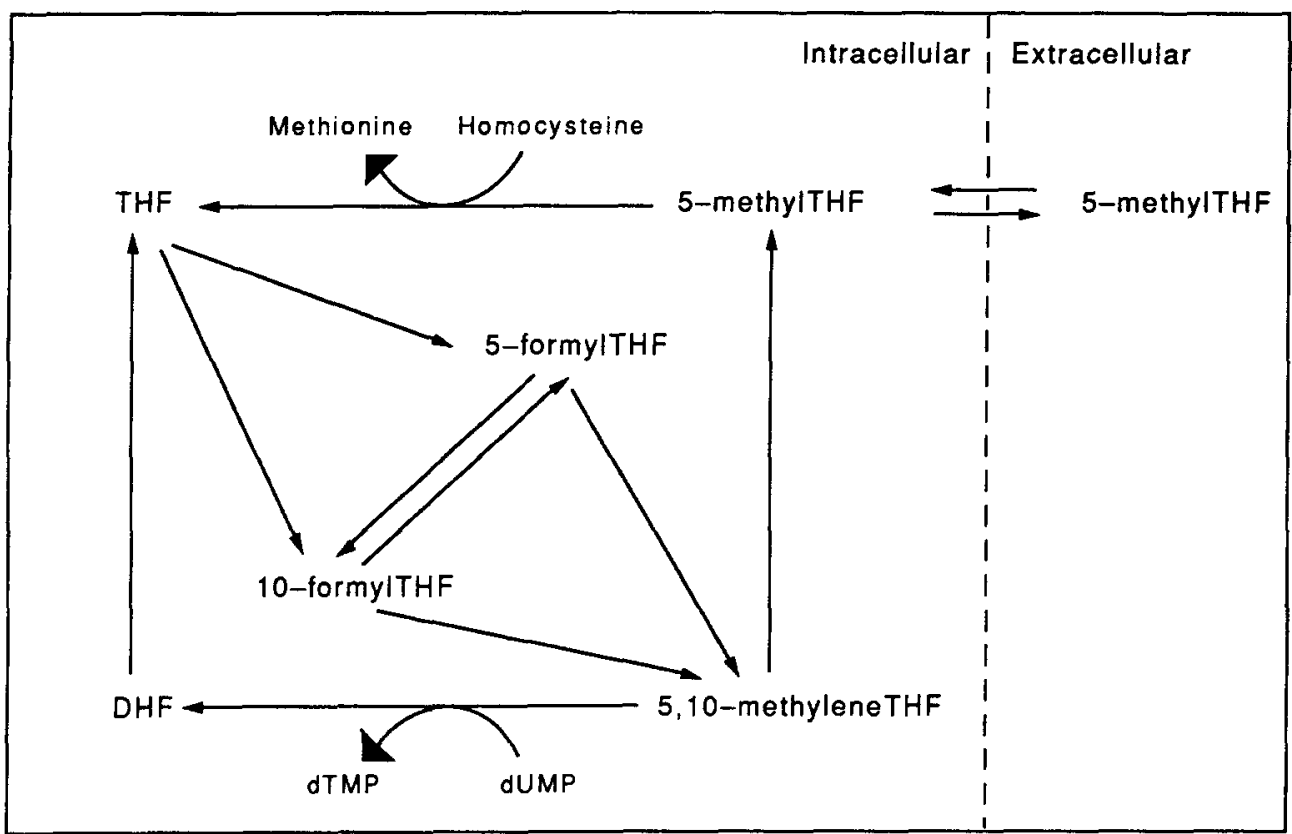

Fig. 1. Outline of the most important intracellular interconversions of reduced folates: $\mathrm{DHF}=$ dihydrofolate; $\mathrm{THF}=$ tetrahydrofolate.

from Flow Laboratories (Rickmansworth, Herts., England). Hog kidney hydrolase was prepared according to the method of McMartin et al. (1981), and pure human transcobalamin II was purified from Cohn's fraction III according to the method of Van Kapel et al. (1981). RPMI 1640 medium and Hanks' balanced salt solution (HBSS) were prepared in the laboratory.

Preparation of bone marrow cell suspension. Bone marrow aspirates were obtained after informed consent from five healthy volunteers. The samples were collected in tubes containing EDTA. The mononuclear cells were isolated by lymphoprep centrifugation and washed with HBSS containing $0.2 \%$ BSA. Monocytes and macrophages were removed by adherence to a large $\left(150-\mathrm{cm}^{2}\right)$ culture flask during a 1-hr incubation of the cells in HBSS with $10 \%$ FCS at $37^{\circ} \mathrm{C}$. Subsequently the cell suspensions were divided into two. One part was used for the determination of the deoxyuridine $(\mathrm{dU})$ suppression test value, and the other part was used for the radioactive labelling of the cellular folate pools.

Radioactive labelling of intracellular folate pools. The cells were labelled with $\left[{ }^{3} \mathrm{H}\right] 5$-formylTHF according to the method of Baram et al. (1987). A suspension of $2 \times 10^{6}$ cells $/ \mathrm{ml}$ in RPMI 1640 (without folic acid or cobalamin), containing $10 \%$ dialysed FCS, $50 \mathrm{nM}-\left[{ }^{3} \mathrm{H}\right] 5$-formylTHF and $40 \mathrm{pm}$ transcobalamin II was prepared. After incubation at $37^{\circ} \mathrm{C}$, under an atmosphere containing $5 \% \mathrm{CO}_{2}$ for $18 \mathrm{hr}$, the cells were washed with $\mathrm{HBSS}$ containing $0.2 \% \mathrm{BSA}$ and resuspended (at $2 \times 10^{6}$ cells/ml) in RPMI 1640, without folic acid or cobalamin, containing $10 \%$ dialysed FCS. After resuspension, $6 \times 10^{6}$ cells were used for direct determination of total intracellular $\left[{ }^{3} \mathrm{H}\right]$ folate content and for HPLC separation of the folate coenzymes (see below).

Exposure of bone marrow cells to nitrous oxide. Both radioactively labelled and unlabelled cell suspensions were divided between four culture flasks $\left(6 \times 10^{6}\right.$ cells in $6 \mathrm{ml}$ RPMI 1640 per flask). From each cell suspension two flasks were exposed to nitrous oxide by flushing for $15 \mathrm{~min}$ with a filtered mixture released from a premixed cylinder. Subsequently, the culture flasks were closed and incubated at $37^{\circ} \mathrm{C}$ for 5 or $10 \mathrm{hr}$. The two other flasks were flushed with a mixture of air and $5 \% \mathrm{CO}_{2}$ for $15 \mathrm{~min}$ and also incubated for 5 or $10 \mathrm{hr}$ at $37^{\circ} \mathrm{C}$. Before and after incubation, cell viability (trypan blue exclusion) and cell concentrations were checked. Total cell loss never exceeded $\mathbf{1 0} \%$.

Quantitation of folate coenzyme pools. After incubation, cells were washed with HBSS containing $0.2 \%$ BSA and counted, and a sample was drawn from each flask for measurement of total intracellular $\left[{ }^{3} \mathrm{H}\right]$ folate content. A standard mixture of unlabelled folates was added to the remaining cells. Subsequently, folates were extracted according to Baram et al. (1987), using a 90-sec boil of the cell pellet in $2 \mathrm{ml} 2 \%$ mercaptoethanol-2\% ascorbic acid (pH 6.0). After treatment for $1 \mathrm{hr}$ with hog kidney hydrolase in order to break down folate polyglutamates, $2 \mathrm{ml}$ of the extraction solution was added before an additional 90 -sec boil. Folates were further purified and concentrated on $C_{18}$ SEP-PAK cartridges, and then separated by reverse phase HPLC essentially as described by Allegra et al. (1986), with the following modifications. The prepared folate 
Table 1. Effect of nitrous oxide exposure on the total intracellular [ ${ }^{3} \mathrm{H}$ ]folate and the distribution of the various folate coenzymes in human bone marrow cells in vitro

\begin{tabular}{|c|c|c|c|c|c|c|}
\hline \multirow[b]{2}{*}{ Treatment } & \multirow{2}{*}{$\begin{array}{l}\text { Total }\left[{ }^{3} \mathrm{H}\right] \text { folate } \\
\text { (pmol } / 10^{6} \text { cells) }\end{array}$} & \multicolumn{5}{|c|}{ Folate coenzymes ( $\%$ of total folate) } \\
\hline & & $\mathrm{N}^{10} \mathrm{~F}$ & $\mathbf{N}^{5} \mathbf{F}$ & DHF & THF & MTHF \\
\hline $\begin{array}{l}\text { Pre-incubation } \\
\text { Control (5 hr) } \\
\mathrm{N}_{2} \mathrm{O}(5 \mathrm{hr}) \\
\text { Control }(10 \mathrm{hr}) \\
\mathrm{N}_{2} \mathrm{O}(10 \mathrm{hr})\end{array}$ & $\begin{array}{l}302 \pm 126 \\
256 \pm 125 \\
238 \pm 85 \\
260 \pm 101 \\
242 \pm 97\end{array}$ & $\begin{array}{l}23 \pm 4 \\
25 \pm 6 \\
19 \pm 6^{*} \\
25 \pm 5 \\
16 \pm 4^{*}\end{array}$ & $\begin{array}{l}7 \pm 1 \\
9 \pm 2 \\
8 \pm 1 \\
9 \pm 2 \\
7 \pm 3\end{array}$ & $\begin{array}{l}3 \pm 2 \\
3 \pm 3 \\
1 \pm 1 \\
4 \pm 3 \\
1 \pm 1\end{array}$ & $\begin{array}{c}8 \pm 2 \\
9 \pm 2 \\
7 \pm 2 \\
10 \pm 2 \\
5 \pm 2 * \\
\end{array}$ & $\begin{array}{l}59 \pm 5 \\
53 \pm 5 \\
65 \pm 8^{*} \\
52 \pm 8 \\
71 \pm 6^{*}\end{array}$ \\
\hline $\begin{array}{l}\mathrm{N}^{10} \mathrm{~F}=10 \text {-formylTH } \\
\text { Values are means } \pm \\
\text { significantly }(\mathrm{Wil} \\
\text { value }(* P<0.05)\end{array}$ & $\begin{array}{l}N^{s} F=5-f o r \\
\text { for five bone } \\
\text { on signed ranl }\end{array}$ & $\begin{array}{l}\text { ITHF } \\
\text { ITHF }=5 \\
\text { arrow sar }\end{array}$ & $\begin{array}{l}\mathrm{F}=\mathrm{dil} \\
\text { ethylT }\end{array}$ & folate & THF $=$ tet & ydrofolat \\
\hline
\end{tabular}

extracts were dissolved in $400 \mu 12 \%$ mercaptoethanol-2\% vitamin $\mathrm{C}$ (pH 6.0). From this extract $200 \mu \mathrm{l}$ was injected onto a Chromsphere C18 column, $200 \times 3 \mathrm{~mm}$ (Chrompack Inc., Bridgewater, NJ, USA). The elution conditions were as follows: 0-15 min, isocratic with $10 \mathrm{~mm}$-ammonium phosphate, 5 mM-Pic A, $12.5 \%$ methanol, pH $5.5 ; 15-49 \mathrm{~min}$, linear gradient from 12.5 to $22 \%$ methanol in same buffer. The flow was $0.4 \mathrm{ml} / \mathrm{min}$. The retention times of the folates were as follows: 10-formylTHF, $21.2 \mathrm{~min}$; THF, $24.2 \mathrm{~min}$; 5-formylTHF, $28.9 \mathrm{~min}$; DHF, $31.9 \mathrm{~min}$; 5-methylTHF, $37.9 \mathrm{~min}$. Samples were collected at 30 -sec intervals. The amount of radioactive folates was determined by liquid scintillation counting. Unlabelled folate standards were detected at $290 \mathrm{~nm}$ with a spectrophotometer (Spectroflow 757, Kratos) and used for identification of the radioactive folate peaks. Background counts in the HPLC eluate were $\pm 100 \mathrm{dpm}$; fractions of folate peaks contained 100-2000 dpm above the background. Before and after analysis of radioactive extracts, unlabelled standard folate mixtures (the same as mentioned above) were injected onto the HPLC system. Calculation of intracellular radioactive folate pools was based on the recovery of the unlabelled folate standards in the cell extract, and the amount of radioactivity in the peaks. Although present in small amounts, 5,10-methyleneTHF could not be quantitated accurately in the present study.

Table 2. Effect of nitrous oxide on de novo synthesis of thymidylate (dTMP) as measured by the deoxyuridine suppression test

\begin{tabular}{lc}
\hline Treatment & dU value $\dagger$ \\
\hline Pre-incubation & $5.5 \pm 1.0$ \\
Control $(5 \mathrm{hr})$ & $6.2 \pm 2.7$ \\
$\mathrm{~N}_{2} \mathrm{O}(5 \mathrm{hr})$ & $11.8 \pm 5.4^{*}$ \\
$\mathrm{Control}(10 \mathrm{hr})$ & $6.3 \pm 2.3$ \\
$\mathrm{~N}_{2} \mathrm{O}(10 \mathrm{hr})$ & $12.5 \pm 4.7^{*}$ \\
\hline+ Results are expressed as the percentage \\
ratio of [ $\left.{ }^{3} \mathrm{H}\right]$ thymidine incorporation \\
with dU to that without dU. \\
Values are means of triple incubations of \\
five bone marrow samples \pm SD. Values \\
marked with asterisks differ significantly \\
(Wilcoxon signed rank test for paired \\
observations) from the corresponding \\
control value ( $P<0.05$ ).
\end{tabular}

Deoxyuridine suppression test. This test was used to evaluate the impairment of the de novo synthesis of dTMP as a consequence of the disturbance of folate metabolism. $\left[{ }^{3} \mathrm{H}\right]$ Thymidine incorporation into DNA is measured with and without the pre-incubation of cells with deoxyuridine (dU). If the folate-dependent dTMP synthesis from dUMP (see Fig. 1) is normal, the pre-exposure to $\mathrm{dU}$ will suppress $\left[{ }^{3} \mathrm{H}\right]$ thymidine incorporation to less than $10 \%$ of the control incubations without $\mathrm{dU}$. However, in the case of disturbed folate metabolism, the decreased de novo dTMP synthesis favours the utilization of $\left[{ }^{3} \mathrm{H}\right]$ thymidine for incorporation into DNA.

The results of this assay are expressed as the percentage ratio of the $\left[{ }^{3} \mathrm{H}\right]$ thymidine incorporation with and without dU in similar cell suspensions. The test was carried out essentially as described by Metz et al. (1968), with some modifications. Briefly, after incubation cells were washed with HBSS containing $0.2 \%$ BSA and counted. $10^{6}$ cells with or without $0.1 \mathrm{mmol} / \mathrm{dU} /$ litre were incubated for $1 \mathrm{hr}$ at $37^{\circ} \mathrm{C}$, followed by another 1-hr incubation in the presence of $0.3 \mu \mathrm{Ci}\left[{ }^{3} \mathrm{H}\right.$ ]thymidine (sp. act. $25 \mathrm{Ci} / \mathrm{mmol}$; Amersham International plc, Bucks., UK). All results were the mean of triple incubations.

Statistical evaluation. The effects of treatment with nitrous oxide were tested against the control values with the Wilcoxon signed rank test for paired observations. Results are presented as mean $\pm \mathrm{SD}$.

\section{RESULTS}

\section{Effect of treatment on total $\left[{ }^{3} \mathrm{H}\right]$ folate content}

During the first $5 \mathrm{hr}$ after the pre-incubation with $\left[{ }^{3} \mathrm{H}\right] 5$-formylTHF some loss of intracellular $\left[{ }^{3} \mathrm{H}\right]$ folate occurred. Table 1 shows that this reduction was caused mainly by a decrease in intracellular $\left[{ }^{3} \mathrm{H}\right] 5-$ methylTHF. The total $\left[{ }^{3} \mathrm{H}\right]$ folate levels of the cells exposed to nitrous oxide tended to be lower than those of control cell suspensions although the differences were not statistically significant.

\section{Effect on intracellular folate coenzyme distribution}

After an initial decrease in the level of 5-methylTHF, the folate coenzyme distribution of the control cell suspensions remained unchanged during the experiments. Exposure to nitrous oxide caused 
significant decreases $(P<0.05)$ in the level of 10 formylTHF after 5 and $10 \mathrm{hr}$. Moreover a $50 \%$ decrease in THF was observed after $10 \mathrm{hr}$ of exposure to nitrous oxide $(P<0.05)$. In contrast with this, there was a time-dependent increase in the 5-methylTHF pool, up to $36 \%$ after $10 \mathrm{hr}$ of nitrous oxide exposure $(P<0.05)$.

\section{Effect on deoxyuridine suppression test}

During the experiments the capacity of the control cell suspensions for de novo dTMP synthesis hardly changed as measured by the $\mathrm{dU}$ test values which were always below $10 \%$. However, in all experiments exposure to nitrous oxide caused an increase of the $\mathrm{dU}$ test values $(P<0.05)$ which indicates a decreased de novo dTMP synthesis. After $10 \mathrm{hr}$ of nitrous oxide exposure, four of the five bone marrow samples gave $\mathrm{dU}$ test values that were above the upper limit of the normal range $(10 \%)$.

\section{DISCUSSION}

Nitrous oxide impairs methionine synthase activity by oxidation of its cobalamin coenzyme. The effects of this 'functional cobalamin deficiency' may be explained by the 'methylfolate trap hypothesis' (Herbert and Zalusky, 1962). This states that during cobalamin deficiency (either nutritional or drug-induced) all folate coenzymes become trapped as 5 -methylTHF, the major folate transport form. Finally this disturbance of the folate metabolism results in impairment of de novo synthesis of dTMP. Over the years the methylfolate trap hypothesis has been supported by the results of several biochemical studies on animal tissues. The present paper for the first time provides information on disturbances of the folate coenzyme distribution of human bone marrow cells during nitrous oxide exposure. However, it should be noted that in this study possible effects on the level of polyglutamation of the folates cannot be detected (Lumb et al., 1985).

Apart from an initial fall in 5-methylTHF, possibly due to transmembrane transport to the folate-free medium, the folate coenzyme distribution of the control cell suspensions remains stable. Exposure to nitrous oxide induces an accumulation of 5 methylTHF at the expense of the other folate forms, the most important of which is the reduction of 10-formylTHF which is an indispensable coenzyme for both AICAR- and GAR-transformylase. These two enzymes are involved in the de novo synthesis of purines. Our results therefore support earlier suggestions that besides impaired dTMP synthesis, disturbance of purine metabolism may contribute to the haematotoxic effect of nitrous oxide (Boss, 1985). In addition, the decrease in intracellular THF, which plays a key role in the overall metabolism of folate, points to the derangement of other folate-dependent pathways.
Levels of 5,10-methyleneTHF, the coenzyme of dTMP synthase, could not be measured because of its low intracellular concentration. Therefore we chose the dU suppression test to measure folatedependent de novo synthesis of dTMP. Exposure in vitro to nitrous oxide for $5 \mathrm{hr}$ reduced the de novo dTMP synthesis of the bone marrow cells. These results concur with studies on anaesthesia patients in which nitrous oxide exposures of 5-6 hr induced abnormal values in the dU suppression test (Kano et al., 1984).

Interestingly, the continued derangement of the folate metabolism that occurs during nitrous oxide exposure for $5-10 \mathrm{hr}$ is not accompanied by further reduction of the de novo dTMP synthesis. Possibly, the relatively small pool of 5,10-methyleneTHF is already depleted after $5 \mathrm{hr}$ of nitrous oxide exposure. If this is so, continued exposure to nitrous oxide would mainly affect other folate-dependent pathways, especially de novo purine synthesis. Although the present paper confirms earlier investigations in animals in vivo, the in vitro effects of nitrous oxide on the folate coenzyme distribution are smaller. The most probable explanations for this are the shorter exposure period (Lumb et al., 1985) and/or the use of a lower concentration of nitrous oxide $\left(50 \% \mathrm{~N}_{2} \mathrm{O}\right)$ in comparison with that used in animal studies ( $70 \%$ $\mathrm{N}_{2} \mathrm{O}$; Wilson and Horne, 1986).

In conclusion, this study demonstrates that the specific redistribution of folate coenzymes during nitrous oxide exposure of human bone marrow cells is in agreement with the theory of 'functional cobalamin deficiency'. Moreover, this study suggests that the haematotoxic effects of nitrous oxide may be based on reductions in synthesis of both dTMP and purine.

\section{REFERENCES}

Allegra C. J., Fine R. L., Drake J. C. and Chabner B. A (1986) The effect of methotrexate on intracellular folate pools in human MCF-7 breast cancer cells. Journal of Biological Chemistry 261, 6478-6485.

Amess J. A. L., Burman J. F., Rees G. M., Nancekievill D. G. and Mollin D. L. (1978) Megaloblastic haemopoiesis in patients receiving nitrous oxide. Lancet ii, 339-342.

Baram J., Allegra C. J., Fine R. L. and Chabner B. A. (1987) Effect of methotrexate on intracellular folate pools in purified myeloid precursor cells from normal human bone marrow. Journal of Clinical Investigation 79, $692-697$.

Boss G. R. (1985) Cobalamin inactivation decreases purine and methionine synthesis in cultured lymphoblasts. Journal of Clinical Investigation 76, 213-218.

Chanarin I., Deacon R., Lumb M., Muir M. and Perry J. (1985) Cobalamin-folate interrelations: a critical review. Blood 66, 479-489.

Deacon R., Perry J., Lumb M. and Chanarin I. (1990) Formate metabolism in the cobalamin-inactivated rat. British Journal of Haematology 74, 354-359.

Duch D. S., Bowers S. W. and Nichol C. A. (1983) Analysis of folate cofactor levels in tissues using high performance liquid chromatography. Analytical Biochemistry 130, 385-392. 
Herbert V. and Zalusky R. (1962) Interrelationships of vitamin B12, methionine and folic acid metabolism: folic acid clearance studies. Journal of Clinical Investigation 41, $1263-1276$

Kano Y., Sakamoto S., Sakuraya K., Kubota T., Taguchi H., Miura Y. and Takaku F. (1984) Effects of leucovorin and methylcobalamin with $\mathrm{N} 2 \mathrm{O}$ anesthesia. Journal of Laboratory and Clinical Medicine 104, 711-717.

Lumb M., Chanarin I., Perry J. and Deacon R. (1985) Turnover of the methyl moiety of 5-methyltetrahydropteroylglutamic acid in the cobalamin-inactivated rat. Blood 66, 1171-1175.

McMartin K. E. N., Nirayotha N. V. and Tephly T. R. (1981) High performance liquid chromatography separation and determination of rat liver folates. Archives of Biochemistry and Biophysics 209, 127-136.

Metz J., Kelly A., Swett V. C., Waxman S. and Herbert V. (1968) Deranged DNA synthesis by bone marrow from vitamin B12-deficient humans. British Journal of Haematology 14, 575-592.

Pheasant A. E., Bates J., Blair J. A. and Nayyiz-Mazhir R. (1983) Investigations of tissue folates in normal and malignant tissues. British Journal of Cancer 47, 393-398. Skacel P. O., Hewlett A. M., Lewis J. D., Lumb M., Nunn J. F. and Chanarin I. (1983) Studies on the haemopoietic toxicity of nitrous oxide in man. British Journal of Haematology 53, 189-200.

Van Kapel J., Loef B. G., Lindemans J. and Abels J. (1981) An improved method for the large scale purification of holo-transcobalamin II. Biochimica et Biophysica Acta 676, 307-313.

Wilson S. D. and Horne D. W. (1986) Effect of nitrous oxide inactivation of vitamin B12 on the levels of folate coenzymes in rat bone marrow, kidney and liver. Archives of Biochemistry and Biophysics 244, 248-253. 